\title{
ON A COLLECTION OF BRAZILIAN LAND PLANARIANS
}

\author{
Claudio G. Froehlich \\ (Dept. of Zoology - Univ. S. Paulo)
}

Dr. Otto Schubart, from the Fisheries Research Station (Estação Experimental de Biologia e Piscicultura) at Piraçununga, State of São Paulo, has kindly forwarded for us to study land planarians he collected during several trips. All the localities are situated in the State of São Paulo, except Ponta Grossa (St. of Paraná) and São José da Barra (St. of Minas Gerais). Nearly all the drawings were made by my wife, Dr. Eudoxia M. Froehlich.

The material comprised the following species:

1. Geoplana vaginuloides (Darw.)

2. G. marginata Fr. Müll.

3. G. kraunsi Gr.

4. G. mullicolor $\mathrm{Gr}$.

5. G. carinata Riest.

6. G. goetschi Riest.

7. G. rosea E. M. Froeh.

8. G. chita C. G. Froeh.

9. G. caapara, n. sp.

10. G. paca, n. sp.

11. G. schubarti, n. sp.

12. G. tapita, n. sp.

13. G. toriba, n. sp.

14. Issoca potyra, n. sp.

15. Bipalium kewense Mos.

\section{Family GEOPLANIDAE Stimpson}

Geoplana vaginoloides (Darwin)

Planaria vaginuloides Darwin, 1844, p. 244.

Geoplana vaginuloides Riester, 1938, p. 72; Marcus 1951, p. 54; 1952, p. 76 . 
Locality: Piraquara, Itanhaen municipality. 1 specimen, 31. VIII. 1941.

The preserved worm measures $38 \mathrm{~mm}$. by $3.8 \mathrm{~mm}$; the mouth is at $21.5 \mathrm{~mm}$., the genital pore at $26.0 \mathrm{~mm}$. from the anterior tip.

The colour pattern is similar to type $\mathrm{C}$ of Marcus (1952, pp. 76-77, pl. 23 fig. 136) but the median reddish stripe is broader (about $1 \mathrm{~mm}$. across, just in front of the pharynx), and both the black and the white stripes that follow on each side are narrower (about 0.2 to $0.3 \mathrm{~mm}$. broad each, in the same region). The median stripe begins at $2.5 \mathrm{~mm}$. from the anterior tip. The creeping sole is greyish white.

As seen in the cleared worm, the anatomy agrees with the previous descriptions of the species (Riester, 1939, and Marcus, 1951). The tubular pharynx is ca. $3 \mathrm{~mm}$. long. The penis papilla is $5.3 \mathrm{~mm}$. long.

\section{Geoplana marginata Fr. Müll.}

Geoplana marginata Fritz Müller, 1857, p. 24.

Geoplana marginata Graff, 1899, p. 305; Marcus, 1951, p. 56.

Locality: Cananeia, in a wood, 1 specimen. 18.XI.1952 .

The preserved worm measures $46 \mathrm{~mm}$. by $3 \mathrm{~mm}$. The mouth is at $23.5 \mathrm{~mm}$., the genital pore at $32.0 \mathrm{~mm}$. from the anterior end. The mesial dorsal stripe is very narrow, the marginal stripes are a little broader than the lateral ones, the colour pattern agreeing, therefore, with that of Marcus, 1951, fig. 151.

The sectioned copulatory apparatus showed that the worm was fully mature. The topography of the copulatory organs (Fig. 1) is similar to that of the worm with inverted copulatory papilla analyzed by Marcus (1. c., fig. 153). There are, however, some differences which may be due to a different state of contraction, to different age, to individual or local variation, or to a combination of these factors. Thus, the seminal vesicle (s) is not straight, but $U$-shaped; one of the efferent ducts (d) opens at the ental end of the vesicle, the other ca. $0,2 \mathrm{~mm}$. ectally; and the male atrium (a) is relatively shorter, and has fewer but larger folds than in Marcus' material. 


\section{Geoplana braunsi Graff}

Geoplana braunsi Graff, 1899, p. 309.

Geoplana braunsi Marcus, 1951, p. 60.

Locality: Ibiti, Amparo municipality, 1 specimen at a coffee plantation, 14.IV.1944.

The preserved worm is $128 \mathrm{~mm}$. long by $11 \mathrm{~mm}$. broad. The mouth is at $76 \mathrm{~mm}$., the gonopore at $92 \mathrm{~mm}$. from the anterior end. The colour pattern agrees with Marcus (1951, p. 60). The collar-shaped pharynx is $11.5 \mathrm{~mm}$. long. The copulatory apparatus, as seen in the cleared worm, coincides with Marcus' (1. c.) description .

\section{Geoplana multicolor Graff}

Geoplana multicolor Graff, 1899, p. 326.

Geoplana multicolor Marcus, 1951, p. 67.

Localities: Guapiara, 4 specimens, 25.XI.1952. Ponta Grossa, state of Paraná, 1 specimen in a backyard, 8.XII.1952.

All specimens present the same colour pattern as the worm of Marcus, 1951, fig. 291, but the median yellow stripe is narrower, only one sixth to one seventh of the body width. The smallest worm is $15 \mathrm{~mm}$. long by $4 \mathrm{~mm}$. broad, mouth at $8 \mathrm{~mm}$., gonopore at $10.5 \mathrm{~mm}$. from the anterior end; the largest (that from Ponta Grossa) is $30 \mathrm{~mm}$. by $5 \mathrm{~mm}$., mouth at 19 , gonopore at $23 \mathrm{~mm}$. from the anterior end. Both these, plus one more from Guapiara were sectioned. The genital apparatus of the two bigger worms were mature and similar to the worm analyzed by Marcus (1. c., pp. 67-8, pl. 28 fig. 177). The smaller worm was incipienthy mature. The female atrium was already filled up by a mass of cells, but the fold that separates the male from the female atria was not yet developed.

\section{Geoplana carinata Riester}

Geoplana carinata Riester, 1938, p. 61.

Geoplana carinata Marcus, 1951, p. 70.

Localities: Piraçununga, at the Fisheries Research Station (Estação Experimental de Biologia e Pesca), 1 specimen, 31.VIII. 
1945. Monte Serrote, near Juquiá, in a banana plantation, 1 immature specimen, 16.XI.1952. Environs of Itapecerica (town $40 \mathrm{~km}$. SW from São Paulo), 1 specimen, 26.V.1954.

\section{Geoplana goetschi Riester}

Geoplana goetschi Riester, 1938, p. 20 .

Geoplana fryi var. bruna Riester, 1938, p. 69.

Geoplana goetschi Marcus, 1951, p. 72.

Locality: Guapiara (town ca. $200 \mathrm{~km}$. WSW from São Pau1o), 1 specimen, 25.XI.1952 .

The preserved worm is strongly contracted, being $40 \mathrm{~mm}$. long by $10 \mathrm{~mm}$. broad. The mouth is at $28 \mathrm{~mm}$., the gonopore at $35 \mathrm{~mm}$. from the anterior end. The colour pattern is similar to that of Bresslau's drawing (Riester, 1938, pl. 1 fig. 20), but the lateral stripes are broader and lighter (Fig. 2). The anatomy of the pharynx and the copulatory organs, as seen is the cleared worm, agrees with Riester's (1. c.) and Marcus' (1951) descriptions.

Geoplana rosea E. M. Froeh.

Geoplana rosea E. M. Froehlich, 1955, p. 317.

Locality: Wcod near Lagoa Infernão, to the west of the mouth of the Rio Jataí, São Simão municipality (ca. $250 \mathrm{~km}$. N from São Paulo), 1 specimen, 28.III.1955.

Geoplana chita C. G. Froeh.

Geoplana chita C. G. Froehlich 1957 (p. 177).

Already studied in the referred paper.

Geoplana caapora, n. sp.

Locality: Environs of Apiaí, town ca. $250 \mathrm{~km}$. WSW from the city of São Paulo; one specimen, 25.XI.1952.

Preserved (Fig. 3), the worm is $21.0 \mathrm{~mm}$. long by $3.2 \mathrm{~mm}$. broad. The mouth is at $14.0 \mathrm{~mm}$., the gonopore at $16.8 \mathrm{~mm}$. from the anterior end. The body presents subparallel margins, it tapers 
rather rapidly to the caudal end, less so to the cephalic end. Both tips are blunt.

The dorsal ground colour (Figs. 3, 5) is light brown (perhaps more yellowish in life). The marginal zone, about a fifth to a fourth of the body width, is dark grey with numerous rounded light spots. These spots are halos around the eyes. At its mesial border, the dark grey zone becomes darker, even black. The broad mesial zone presents, on the ground colour, irregular grey to black patches with rounded indentations, resulting in a mottled appearance. The anterior end (Fig. 4) is also mottled. The ventral side is light grey.

The eyes (Fig. 6) begin marginally and in one row at the anterior tip, but shortly backwards become pluriserial, and at ca. $3.5 \mathrm{~mm}$. from the tip spread on the dorsal surface to about one third of the body width on each side. The dorsal eyes are surrounded by light halos.

Pharynx (Fig. 7) cylindrical; pharynx pocket small; mouth (c) at posterior end of pocket.

Efferent ducts (Fig. 8, d) containing few spermatozoa. Masses of extravasated sperm ( $\mathrm{sp}$ ), issued from burst points of efferent ducts, present in parenchyma near to seminal vesicle ( $s$ ). Ental part of seminal vesicle paired, with globular dilated lateral portions, each receiveng ventroposteriorly the corresponding efferent duct. Paired part of vesicle, especially globular portions, receives numerous fine-grained eosinophilous and sparse cyanophilous glands. Common part with few glands. Lining epithelium of vesicle columnar, nonciliated, up to $75 \mu$ high in globular portions. Ejaculatory duct (e) with narrower lumen than vesicle; nonciliated, and with sparse cyanophilous glands in its ental half; ciliated and with no glands in ectal half. Penis papilla ( $p$ ) massive, ca. $0.55 \mathrm{~mm}$. long, almost filling up male atrium. Muscularis of papilla rather strong. Basal part of papilla, and atrium are lined by a nonciliated, irregular glandular epithelium. Both eosinophilous and cyanophilous secretion is poured into atrium, the former as balls detached from the epithelium. At tip of papilla opens numerous coarse granular eosinophilous glands, not deeply stained. The ciliated gonopore canal issues from posterior part of male atrium. 
Vitellaria mature. Both oviducts (o) contain spermatozoa, indicating recent copulation. Lining epithelium of oviducts containing at free border an accumulation of eosinophilous granules, apparently of epithelial origin. Oviducts begin to rise in front of gonopore. Ascending portion of left oviduct simple, that of right oviduct forks into three branches; two of these branches reunite shortly on, and farther on, with the third branch. Shell glands restricted to ectal portions of oviducts. Oviducts open into a very short female genital canal, a dorso-posterior process of the female atrium. Female atrium globular, opening into male, and filled by a compact mass of cells, looser and mixed with a deeply staining eosinophilous secretion at its central and outer portions. Ventroanteriorly the female atrium presents a recess, connected also to male atrium, and dilated a little to the left.

The colour pattern of $G$. caapora is distinctive, for no other species of Geoplana presents the combination of a grey marginal zone provided with light halos, with a mottled median zone due to an irregular network of grey to black pigment. The colour pattern of G. fragai C. G. Froeh. (1955b, p. 197 figs. 4-5) presents a certain similarity, but it has light margins to which the eyes are restricted, no light halos occur in the lateral dark stripes, and in the marbled median zone the pigment occurs chiefly in small longitudinal strips.

The copulatory apparatus of $G$. caapora presents a striking resemblance to that of G. multicolor Gr., the chief difference being the absence, in $G$. caapora, of a muscular fold separating the male from the common genital atrium. The pharynges of the two species are also similar. The different colour patterns, however, force their separation.

\section{Geoplana poca, n. sp.}

Locality: Piraquara, Itanhaen municipality; one specimen, 30. VIII.1941.

Preserved, the worm is $20 \mathrm{~mm}$. long by $5 \mathrm{~mm}$. broad. The mouth is at $\mathbf{1 2 . 5}$, the gonopore at $14 \mathrm{~mm}$. from the anterior tip. The broadest part of the body is situated at the limit of the third and fourth quarters of its length. From this point it tapers gradually to the 
anterior end, rapidly to the posterior one. Ground colour of dorsal side yellow with ferruginous tints. Two lateral black stripes run longitudinally on the back. The inner borders of the stripes are sharply delimited against the ground colour, the outer ones fade towards the margins. Mesially runs a pale dark stripe, formed by elongated dark-gray spots. On the second half of the animal this stripe has darker borders. At the margins of the body there is also a concentration of pigment. The ventral side presents a pale yellowish colour.

The eyes (Fig. 10) begin uniserially at each side of the anterior tip, and shortly backwards become pluriserial and crowded. From ca. $3.5 \mathrm{~mm}$. from the anterior tip on, the eyes spread onto the back, some advancing into the light median zone. The dorsal eyes are surrounded by light halos, bigger in the second third of the body.

Pharynx (Fig. 11) cylindrical; mouth (c) at caudal end of pharynx pocket.

Efferent ducts (Fig. 12, d) full of spermatozoa. Seminal vesicle (s) simple, tubular, looped, extrabulbar, receiving separately the efferent ducts at ental end. Cilia of vesicular lumen 13-15 long. Unstained glands open into vesicle. Ejaculatory duct (e) narrower than vesicle, ciliated, provided with eosinophilous glands, and slightly winding in the three ental fourths. In ectal fourth there is a contorted portion, then the duct widens into a short glandular, nonciliated portion $(u)$, which receives eosinophilous glands different from those of ental part. This portion is followed by a final one with similar epithelium, but with fewer glands. Penis papilla (p), ca. $0.9 \mathrm{~mm}$. long, nearly fills up genital atrium (ac). Posteroventrally on surface of papilla there is a glandular region, where cpens numerous weakly eosinophilous glands (y); rest of papilla ccated by an epithelium similar to that of ectal part of ejaculatory duct. Genital atrium lined by a high (70 $\mu$, locally), irregular, glandular, columnar epithelium. Subepithelial cyanophilous glands open into atrium. Gonopore $(\mathrm{g})$ near $(0.25 \mathrm{~mm}$.) to ventral insertion of penis papilla.

Vitellaria mature. Oviducts (o) rise caudally to gonopore, bend medially and unite into a common oviduct ( $q$ ) directed ven- 
trally. Transverse ectal parts of paired oviducts and common part function as glandular ducts. Common glandular duct open into female atrium, dorso-posteriorly situated in relation to rest of genital atrium. Female atrium separated from this by a fold, which is probably a consequence of pressure exerted by tip of penis papilla against atrial wall.

The colour pattern of $G$. poca is somewhat similar to that of G. multicolor Gr., but the lateral black stripes (brown or dark brown in G. multicolor) are narrower, and the margins present a concentration of pigment, absent in G. multicolor. The eye distribution is also different, G. poca presenting the anterior crowding, absent in G. multicolor.

By the anatomy of its copulatory organs, G. poca belongs to Group $\mathbf{C}$ of Brazilian Geoplanas. As regards the size of the penis papilla, it stands between G. yara E. M. Froeh. and G. taxiarcha Marc. but differs markedly from both in the female part of the copulatory apparatus. The short common glandular duct opening difectly into dorso-posterior part of the genital atrium is distinctive.

Geoplana schubarti, n. sp.

Localities: Piraquara, Itanhaen municipality (Itanhaen city ca. $70 \mathrm{~km}$. south of the city of São Paulo); 2 specimens in a bromelia, 30.VIII.1941; Dr. Schubart col.. Cidade Jardim, a residential quarter in the city of São Paulo; 1 specimen in a small wood, 27.V.1951; Prof. E. Marcus col.

Measures, im mm., of the preserved worms:

$\begin{array}{ccccc}\text { Provenience } & \text { length } & \text { width } & \text { mouth } & \text { gonopore } \\ \text { Piraquara } & 30.0 & 7 & 16.0 & 19.0 \\ \text { " } & 20.0 & 5 & 12.5 & 14.5 \\ \text { São Paulo } & 26.0 & \text { ca. } 3 & 16.0 & 18.8\end{array}$

The difference in the relative width between the specimen form S. Paulo and those from Piraquara is due to contraction, for the latter were killed with cold alcohol, the former with not fixative (Susa). The specimen from S. Paulo measured, when creeping, $30 \times 3 \mathrm{~mm}$. 
On the back (Figs. 16, 18) there are three longitudinal black stripes the median one being about half as wide as the broad lateral stripes. The ground colour is orange in the preserved material from Piraquara, light yellow in the specimen from S. Paulo, both living and fixed. It shows itself between the dark stripes and around the margins of the body. The broad creeping sole (Fig. 17), almost as wide as the body, is light grayish-yellow, passing to a darker colour at the anterior and, less intensely, at the posterior end.

At the cephalic end (Fig. 13), the eyes are marginal, in irregular rows. Around the anterior tip the row is discontinuous. At 3 to $4 \mathrm{~mm}$. from the anterior tip, the eyes begin to spread onto the dorsal side. In the smaller worm from Piraquara (Fig. 15), the eyes spread into the light zone between the lateral and the median stripes; in the other two specimens (Fig. 14), the eyes stop at the border of the lateral stripes. Within the dark stripes the eyes are surrounded by small light halos.

Pharynx (Figs. 19, 22) cylindrical. Pharyngeal pocket may present a caudal diverticulum $(t)$ or not (smaller worm from Piraquara).

The two worms from Piraquara are fully mature. The tubular, extrabulbar, contorted seminal vesicle (Fig. 22, s) receives entally and laterally the efferent ducts (d) full of spermatozoa. Into the vesicle opens eosinophilous glands. The ejaculatory duct (e), of smaller calibre than the seminal vesicle, traverses slightly sinuously the penis papilla $(p)$. Both vesicle and ejaculatory duct lined by a cubical or columnar epithelium provided with long cilia (ca. $12 \mu$ long in seminal vesicle). Penis papilla large, protruded in both specimens, in the larger one (Fig. 22) broken flush with the ventral surface; in the smaller one about $2 \mathrm{~mm}$. long (Fig. 17, p). On the surface of the penis papilla opens eosinophilous and sparse cyanophilous glands.

Vitellaria fully mature. The oviducts (Fig. 22, o) rise behind gonopore $(\mathrm{g})$. Shell glands $(z)$ open into the ectal parts of the oviducts and into the short common portion (q). Tubular ental part (female genital canal, "vagina") of female atrium directed dorsally and forward. Whole genital atrium lined by a high, nonci- 
liated irregular epithelium, with eosinophilous border, and receiving subepithelial cyanophilous glands.

The male part of the genital organs of the specimen from São Paulo (Fig. 20) is mature. The efferent ducts are full of spermatozca. The large penis papilla $(p)$ is retracted! into the genital atrium (ac). The female part is not yet mature. Vitellaria are not developed, and the shell glands ( $z$ ) are incipient.

By its colour pattern, G. schubarti stands isolated among Brazilian Geoplanas. It is similar to G. aymara du B. R. Marc. from Peru, but this species has broader latero-marginal stripes that extend to the margin of the body. Besides, in G. schubarti the eyes spread much farther on the back than in G. aymara; the pharynx is less folded, and the female part of the ccpulatory apparatus is quite different.

By the anatomy of the copulatory aparatus, G. schubarti belongs to Group C of Brazilian Geoplanas, standing near G. livia, E. M. Froeh., G. riesteri C. G. Froeh. and G. joia C. G. Froeh., but the colour pattern is wholly different from any of these species.

\section{Geoplana tapira, n. sp.}

Locality: Tapiraí, a small village ca. $100 \mathrm{~km}$. WSW of the city of São Paulo, between Piedade and Juquiá; one specimen in a wcod, 15.XI.1952.

The preserved worm (Fig. 21 ), $38 \mathrm{~mm}$. long by $12 \mathrm{~mm}$. broad, is strongly contracted for being preserved in cold fixative (alcohol). The mouth is at 27 , the gonopore at $32 \mathrm{~mm}$. from the anterior tip. The body is broad, with subparallel margins; it narrows rather abruptly at both ends, less so at the anterior one, which ends in a pointed tip.

On the back there is a pair of longitudinal black stripes separated by a median light line. Each stripe is $2-2.5 \mathrm{~mm}$. broad. Towards the ends they narrow and posteriorly stop at a distance from the tip. The ground colour, evident in the median line and at the broad latero-marginal zones, is yellowish-ochre. The ventral side is dirty yellow with a narrow border of the dorsal ground colour; the anterior tip is brown. The sensory border (Sinneskante) is visible to about $7 \mathrm{~mm}$. from the tip. 
The eyes (Fig. 23) circle the anterior end in one row, and then become pluriserial, but dces not spread on the dorsal surface more than $0.8 \mathrm{~mm}$. on each side.

Pharynx (Fig. 24) cylindrical, long, ca. $5 \mathrm{~mm}$. long from insertion; free borcer richly folded. Pharynx pocket extends backwards to the vicinity of the seminal vesicle.

Worm incipently mature. Up to five testes in same side of transverse sections. Testes with no ripe spermatozoa. Empty efferent ducts (Fig. 25, d) open separately into seminal vesicle ( $s$ ), extrabulbar in position, but enveloped by fibres common to penis bulb. Epithelium of vesicle columnar, ciliated, containing ducts of ecsinophilous and weakly cyanophilous glands. Ejaculatory duct (e) newly opened, simple, lined by a cubic epithelium with cyanophilous border. Penis papilla (p) massive, ca. $1 \mathrm{~mm}$. long, filling up male atrium; tip of papilla bent to the right. Male atrium (a) separated from female by a constriction.

Vitellaria absent. Oviducts (o) rise in front of gonopore ( $g$ ) and fuse dorsally into a common oviduct (q) directed backwards, that opens dorsally into middle part of female artium. Shell glands not yet formed. Female atrium filled up by a mass of cells (r), many of them containing eosinophilous granules. Gonopore canal exits from ventro-anterior part of female atrium.

G. bilinearis (Darw.), G. bilineata Fuhrm., and G. theresopolitana Schirch, known only by external characters, are species with a pair of dark stripes on the back, but are smaller and more slender species than, and the position of the stripes is different from G. tapira. G. gabriellae du B.-R. Marcus has also two dark dorsal stripes, but the position of the stripes, and the anatomy of the copulation organs are different.

Like several species of Geoplana (cf. E. M. Froehlich, 1955, p. $329)$, G. tapira presents a mass of cells of unknown function in the female atrium. Besides this common feature, G. tapira is distinct from any of these. Riper worms are needed for judging its relationships within the genus. 
Geoplana toriba, n. sp.

Locality: Monte Serrote, near Juquiá (town ca. $130 \mathrm{~km}$. SW of São Paulo); 1 specimen in a banana plantation, 16.XI.1952 .

Preserved (Fig. 28), the worm is $40.5 \mathrm{~mm}$. long by $5.0 \mathrm{~mm}$. broad. The mouth is at 24.7 ; the gonopore, at $28.2 \mathrm{~mm}$. from the cephalic tip. The body is rather flat, with subparallel margins. Both anterior and posterior narrowings rapid, but not abrupt.

On the back there are two pairs of narrow dark stripes, one pair marginal, the other bordering a reddish ochre median zone. Between the marginal and the submedian stripes there is a yellow zone. The submedian pair fuse both anteriorly and posteriorly. Halos of eyes occur in the marginal stripes and in the median zone, those of the latter being larger. The ventral side is light grey. The grey tint is due to a loose net of dark pigment.

Except to about $7 \mathrm{~mm}$. from the anterior tip, where they are maiginal (Fig. 29), the eyes spread onto the whole dorsal side (Fig. 30). The pigment cups of the larger anterior eyes have a diametre of ca. $55 \mu$ and a length of $75 \mu$.

Pharynx (Fig. 26) cylindrical, contracted, $1.3 \mathrm{~mm}$. long from ventral insertion. Pharynx pocket $2.5 \mathrm{~mm}$. long.

Efferent ducts (Fig. 27, d), containing spermatozoa but not dilated into spermiducal bulbs, open into paired transverse portions of extrabulbar seminal vesicle (s). Seminal vesicle tubular, bent, lined by a cubic ciliated epithelium, and receiving eosinophilous and weakly cyanophilous glands. Ejaculatory duct (e) similar to vesicle, but lacking eosinophilous glands; its bulbar portion and ental papillar portion, looped; rest of papillar portion nearly straight, opening at tip of papilla. Penis papilla (p) $0.7 \mathrm{~mm}$. long. Near the posterior end of the papilla a circular flap encloses partially the tip. Epithelium of penis cubical to columnar, irregular, nonciliated. Male atrium separated from female by a pair of lateral folds. Epithelium of male atrium columnar, irregular, nonciliated, with free border full of eosinophilous granules. On a projecting atrial fold over the penis papilla open numerous cyanophilous glands $(y)$, into the rest of the male atrium, scarce cyanophilous glands.

Vitellaria mature. Oviducts (o) rise very steeply, caudally to gonopore. Shell glands $(z)$ open into ectal half of the ascending 
portion of the oviducts, into final transverse portions of the same, and into short, postero-ventrally directed, common glandular duct (q). This duct continuous with female genital canal ("vagina"), the ental tubular part, upward turned, of the female atrium. Female atrium (f) ample, lined by an epithelium similar to that of male atrium, but higher and with a thicker layer of eosinophilous granules at the free border. Genital pore canal issues from anterior part of female atrium.

G. rostrata Gr. has also two pairs of black stripes on the back, but the central pair has a more lateral position than in G. toriba, resulting in a broader median zone. This zone is plain yellow, not ochraceous with light halos, and the eyes do not enter into it. Besides, G. rostrata has a pair of gray stripes on the ventral surface, absent in G. toriba.

By the structure of the copulatory apparatus, G. toriba belongs to group $\mathrm{C}$ of Brazilian Geoplanas, standing near to G. pavani Marc., which presents, however, a much bigger seminal vesicle, and a smaller penis papilla. The colour pattern of these two species are wholly different, G. pavani being spotted.

Issoca potyra, $\mathrm{n}$. sp.

Locality: Eldorado (formerly Xiririca), town on the Rio Ribeira (Ribeira River), ca. $190 \mathrm{~km}$. SW from the city of São Paulo, 1 specimen in a coffee plantation, 21.XI.1952.

Preserved (Fig. 31), the worm is $39 \mathrm{~mm}$. long by $5.5 \mathrm{~mm}$. broad. The mouth is at 21.7 , the genital pore at $30.2 \mathrm{~mm}$. from the anterior end. From its broadest part, about the middle, the body tapers gradually to both ends. The anterior end is blunt, due to the presence of the glandulo-muscular organ.

On the back there is a pair of black longitudinal stripes, ca. $1 \mathrm{~mm}$. broad each, at the pharynx level. At the same level, the median zone encolosed by them is $0.8 \mathrm{~mm}$. broad. The dorsal epidermis is irregularly spotted with brown. The parenchyma, except for the dark stripes, has no pigment, being of a light yellowish-grey colour. In life the ground colour is probably lighter, for after some time the epidermis (specially the rhabdoids) darkens in the usual preserving fluids (alcohol and formalin). The ventral side is light 
yellowish-grey, with a narrow brown border; at the anterior end (Fig. 32 ) is found the broad horseshoe-shaped glandular surface. The position of the sensory tract (Sinneskante) is similar to that of I. rezendei (C. G. Froehlich, 1955a, pl. 8 f. 46).

The eyes circle the anterior tip (Fig. 33) in one row. The foremost eyes are provided with long pigment cups, 50-60u. long by $20.27 \mu$ wide; the rest of the eyes present the ordinary short cups with a diametre of $30-45 \mu$. Abcut $4 \mathrm{~mm}$. from the anterior tip, the eyes spread on the dorsal surface (Fig. 34) to the black stripes, where they are surrounded by small light halos.

The structure of the glandula-muscular organ (Fig. 35) is similar to those of the other species of the genus (C. G. Froehlich, 1. c., p. 226, p1. 9).

Pharynx (Fig. 36) cylindrical with dorsal insertion caudally displaced, approaching bell type (Glockenförmig) of Graff. Mcuth (c) at beginning of second third of pharynx pocket.

Efferent ducts (Fig. 37, d), full of spermatozoa, open into each side of seminal vesicle (s). Seminal vesicle (Fig. 38) extrabulbar, complex, with numerous interconnections between its parts. Ental two thirds of ejaculatory duct (Fig. 37, e) wide and irregular, ectal third tubular. Both vesicle and ejaculatory duct receive cyanophilous and eosinophilous glands, and are lined by a cubic or low columnar ciliated epithelium. Ejaculatory duct opens on ventral side of short conical penis papilla $(p)$. In neighbourhood of ejaculatory duct opening, papilla lined by a cubical nonciliated epithelium. Rest of penis papilla, as well as male atrium (a), lined by a columnar, nonciliated epithelium provided with an accummulation of erythrophilous granules at the free border. At ectal end of male atrium, especially on the dorsal fold $(x)$ that separates it from female atrium, open numerous cyanophilous glands (w).

Vitallaria fully mature. Oviducts (o) begin to rise in front of gonopore $(\mathrm{g})$. Shell glands $(\mathrm{z})$ open into ectal ascending portion and into transverse final portion of paired oviducts, and into backwards directed common glandular duct $\left(\mathrm{a}_{1}\right)$. This duct opens into ental, slightly dilated portion of female atrium, separated from the rest of the atrium by a constriction. Whole female atrium (f) lined by an epithelium similar to that of male atrium, but receiving 
numerous cyanophilous glands. Muscular coat of female atrium distinct from that of male (which is here the penis bulb musculature). Genital pore canal issues from anterior part of female atrium. Issoca potyra differs from the known species of the genus in having but one pair of dark stripes. It bears a certains likeness to I. piranga C. G. Froeh., which has a pair of broad lateral black strifes, and one of narrow marginal ones. As regards the copulatory apparatus, $I$. potyra stands near $I$. piranga too. This species has, however, a simple seminal vesicle, a narrower ejaculatory duct, and a more folded atrium.

\section{Family BIPALIIDAE Graff}

\section{Bipalium kewentse Mos.}

Localities: Ibiti, Amparo municipality, 1 specimen, april 1944 São José da Barra, Minas Gerais State, 2 specimens under a rotting log in a grazing field, 1.III.1953.

\section{Resumo.}

Neste trabalho são estudadas taxonômicamente planárias terrestres coligidas em diversas excursões pelo Dr. Otto Schubart. O material incluia 15 espécies, das quais 6 novas. Quase todo o material provém do Estado de São Paulo.

\section{REFERENCES}

Du BOIS-REYMOND MARCUS, E., 1951 - On South American Geoplanids. Bol. Fac. Fil. Ci. Letr. Zoologia n. 16, pp. 217-255, pls. 1-8. São Paulo.

DARWIN, Ch., 1844 - Brief Descriptions of several Terrestrial Planaria and of some remarkable Marine Species, etc. Ann. Mag. Nat. Hist. V. 14, pp. 241-251, pl. 5 figs. 1-4. London .

FROEHLICH, C. G., 1955a - Sôbre morfologia e taxonomia das Geoplanidae. Bol. Fac. Fil. Ci. Letr. Zoologia n. 19, pp. 195279, 14 pls. São Paulo.

- 1955b - Notas sôbre geoplanas brasileiras. Pap. Av. Dep. Zool. Secr. Agric. S. Paulo v. 12 n. 7, pp. 189-198, 6 figs. São Paulo.

1956 - Tricladida Terricola das regiōes de Teresópolis e Ubatuba. Pap. Av. Dep. Zool. Secr. Agric. S. Pallo v. 12, pp. 313-343, 56 figs. São Paulo. 
— 1957 - Planárias Terrestres do Paraná. Dusenia, vol. 7 n. ${ }^{\circ}$ 4, pp. 173-191, pls. 4-8. Curitiba.

FROEHLICH, E. M., 1955 - Sôbre espécies brasileiras do gênero Geoplana. Bol. Fac. Fil. Ci. Letr. Zoologia n. 19, pp. 289-369, 16 pls. São Paulo.

FUHRMANN, O., 1914 - Planaires terrestres de Colombie. Mém. Soc. Neuchât. Sci. Nat. v. 5, pp. 748-792, pls. 15-17. Neuchâtel.

GRAFF, L. von, 1899 - Monographie der Turbellarien II. Tricladida Terricola. v. 1, XIII + 574 pp.; v. 2, 58 pls. Leipzig (Engelmann).

MARCUS, E., 1951 - Turbellaria Brasileiros (9). Bol. Fac. Fil. Ci. Letr. Zoologia n. 16, pp. 5-215, 40 pls. São Paulo.

__ 1952 - Turbellaria Brasileiros (10). Bol. Fac. Fil. Ci. Letr. Zoologia n. 17, pp. 5-187, 32 pls. Sāo Paulo.

RIESTER, A., 1938 - Beiträge zur Geoplaniden-Fauna Brasiliens. Abh. Senckenb. Naturf. Ges. Abh. 441, pp. 1-88, pls. 1-2. Frankfurt a. M.

SCHIRCH, P., 1929 - Sôbre as planárias terrestres do Brasil. Bol. Mus. Nacional v. 5, pp. 27-38, 4 pls. Rio de Janeiro.

SCHULTZE, M. e MÚLLER, F., 1857 — Beiträge zur Kenntnis der Landplanarien, etc. Abh. Naturf. Ges. Halle v. 4, pp. 19-38. Halle a. S. 


\section{PLATES}




\section{PLATE 1}

Geoplana marginata Fr. Müll.

Fig. 1 - Copulatory apparatus, combined sagittal sections.

Gecplana gcetschi Riest.

Fig. 2 - Colcur pattern of dorsal side.

Gecplana caapora, n. sp.

Fig. 3 - Dorsal view of preserved worm.

Fig. 4 - Dorsal view of anterior tip.

Fig. 5 - Dorsal view, about the middle of the body.

Fig. 6 - Distribution of the eyes at the anterior end. The tip is bent to the right.

Fig. 7 - Median section of pharynx.

Fig. 8 - Copulatory apparatus, combined sagittal sections.

a, male atrium; b, penis bulb; c, mouth; d, efferent duct; e, ejaculatory durt; f, female atrium; g, gonopore; i, intestine; $\mathbf{k}$, muscularis of pharynx; m, muscle coat of copulatory apparatus; o, oviduct; p, penis papilla; q, common glandular duct; r, mass of cells of female atrium; s, seminal vesicle; sp, mass of spermatozoa; $y$, eozinophilous glands; $z$, shell glands. 
On a Collection of Brazilian Land Planarians

1

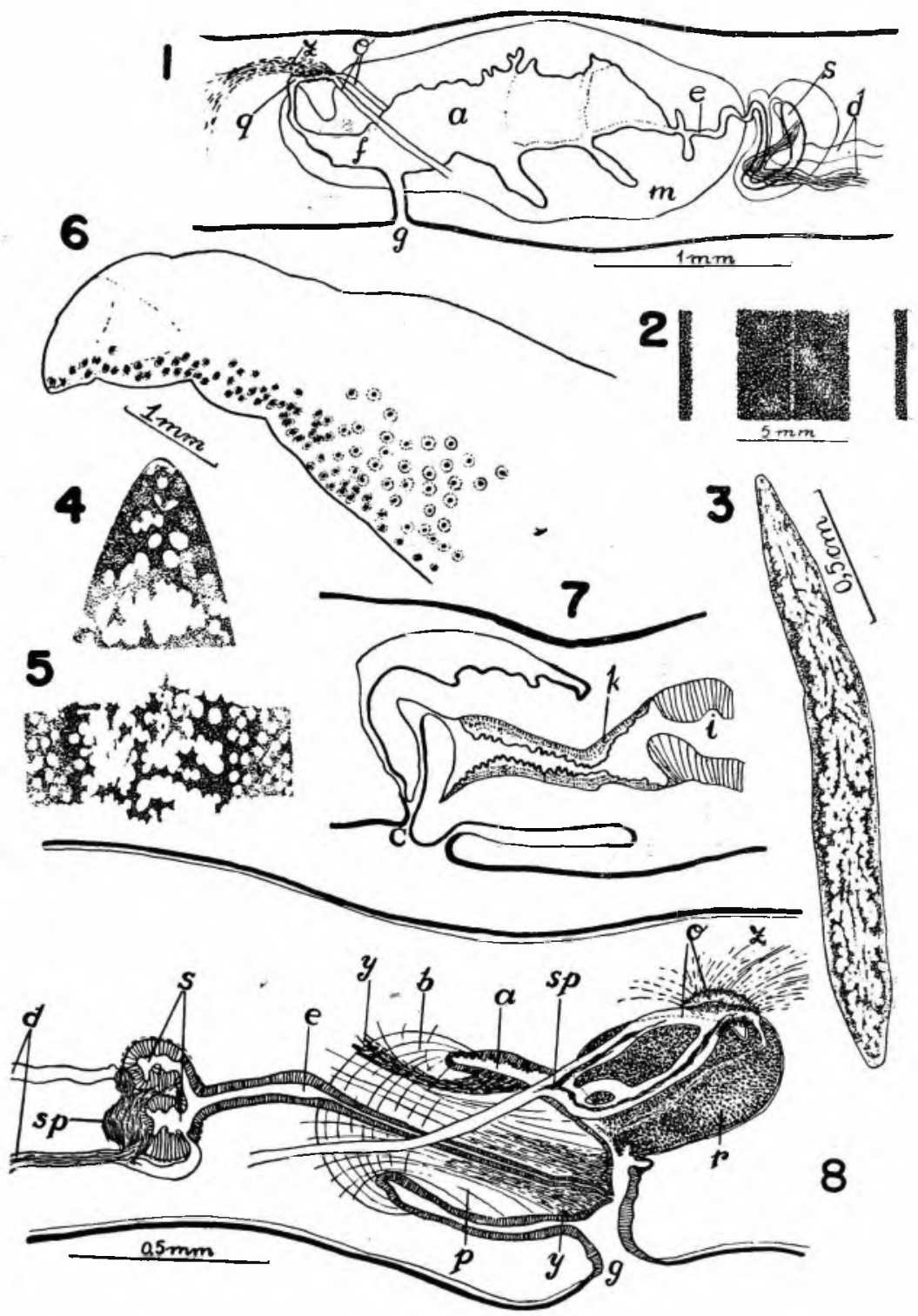




\section{PLATE 2}

\section{Geoplana poca, n. sp.}

Fig. 9 - Dorsal view of preserved worm.

Fig. 10 - Distribution of the eyes at the anterior portion of the body.

Fig. 11 - Pharynx, median section.

Fig. 12 - Copulatory apparatus, combined sagittal sections.

Geoplana schubarti, n. sp.

(also pl. 3, Figs. 16-20; pl. 4, Fig. 22)

Fig. 13 - Distribution of the eyes at the anterior end (larger specimen from Piraquara).

Fig. 14 - Distribution of the eyes in front of the pharynx (larger specimen from Piraquara).

Fig. 15 - Distribution of the eyes in front of the pharynx (smaller specimen from Piraquara).

ac, common genital atrium; b, penis bulb; c, mouth; id, efferent duct; e, ejaculatory duct; g, gonopore; $i$, intestine; o, oviduct; $p$, penis papilla; q, common glandular duct; s, seminal vesicle; $u$, dilated portion of ejaculatory duct with eosinophilous glands; $y$, eosinophilous glands; $z$, shell glands. 


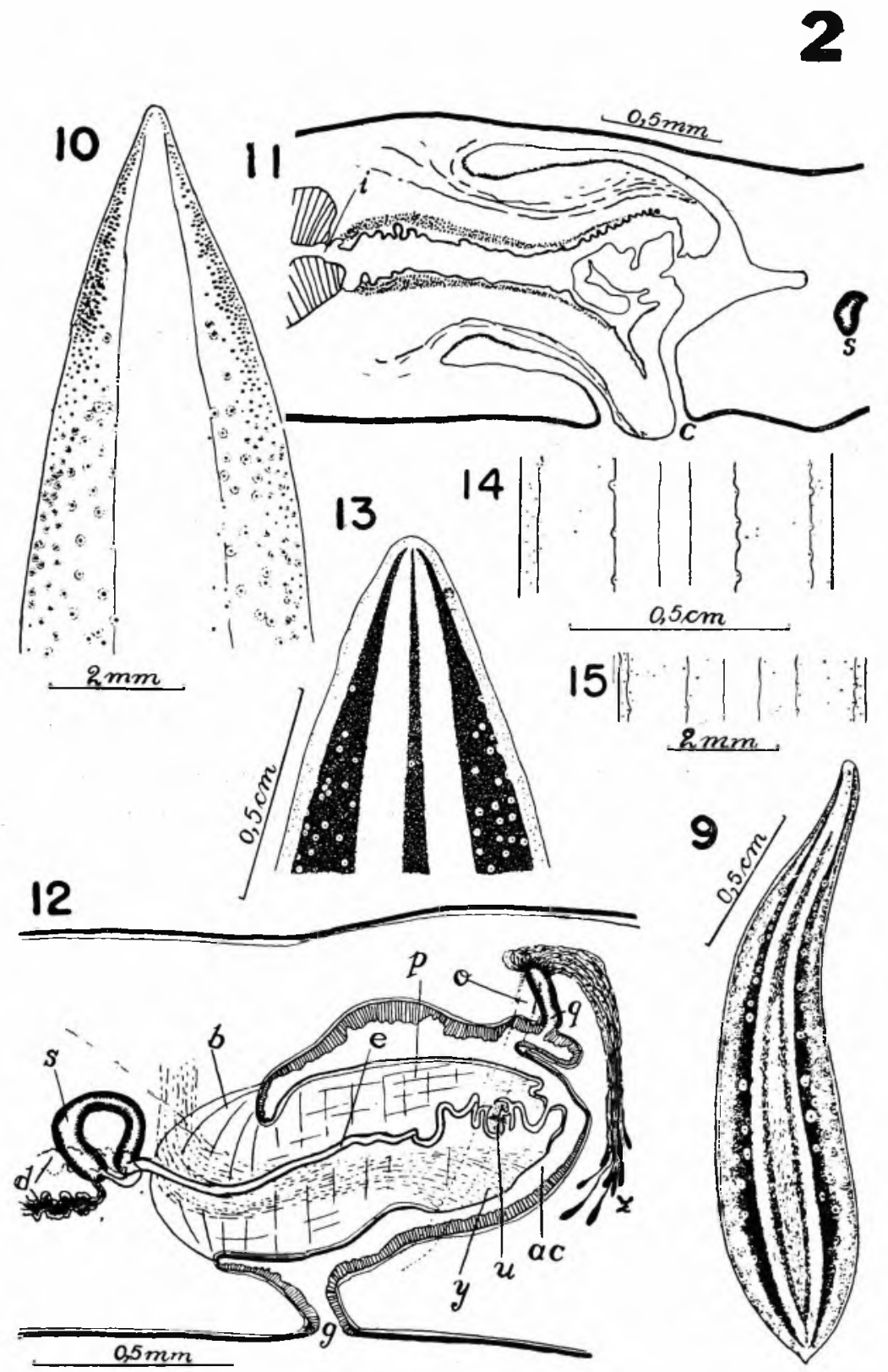




\section{PLATE 3}

Geoplana schubarti, n. sp. (also pl. 2, Figs. 13-15; pl. 4, Fig. 22)

Fig. 16 - Dorsal view (larger worm from Piraquara).

Fig. 17 - Ventral view (smaller worm from Piraquara).

Fig. 18 - Dorsal view (specimen from São Paulo).

Fig. 19 - Median section of the pharynx (specimen from São Paulo).

Fig. 20 - Copulatory apparatus, combined sagittal sections (specimen from São Paulo).

Geoplana tapira, n. sp.

(also pl. 4, Figs. 23-25)

Fig. 21 - Dorsal view of preserved specimen.

ac, common genital atrium; b, penis bulb; c, mouth; $d$, efferent duct; e, ejaculatory duct; $g$, gonopore; $i$, intestine; $\mathbf{k}$, muscularis of pharynx; o, oviduct; $p$, penis papilla; q, common glandular duct; s, seminal vesicle; sb, sensory border; $t$, pharynx pocket; $v$, female genital canal (vagina). 


\section{3}
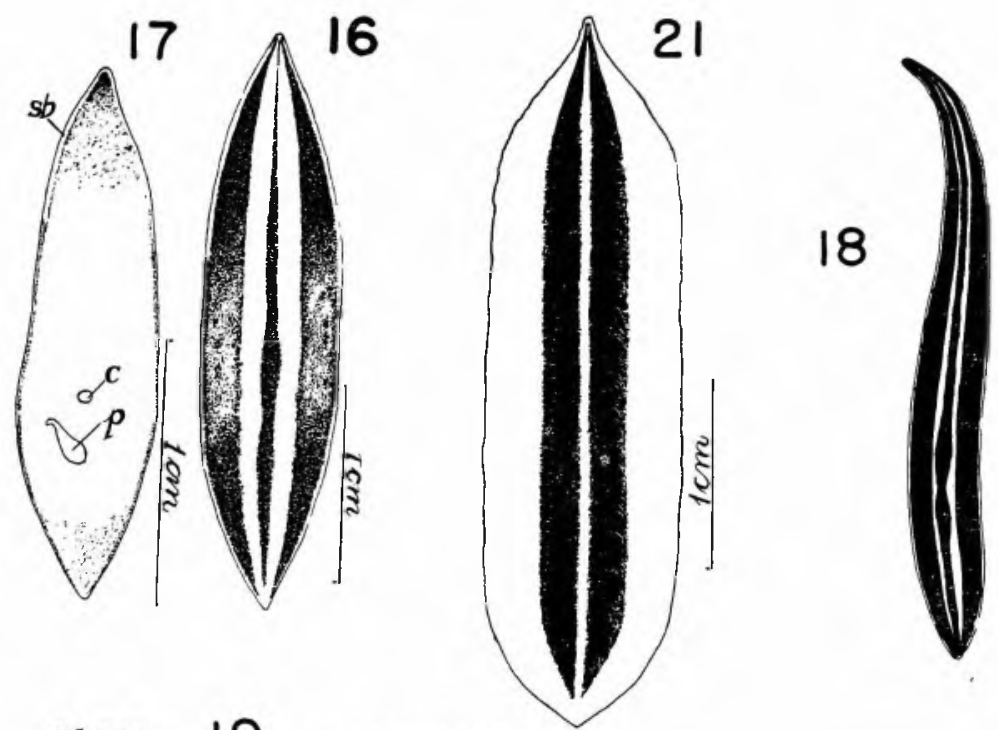

$0.5 \mathrm{~mm}-19$

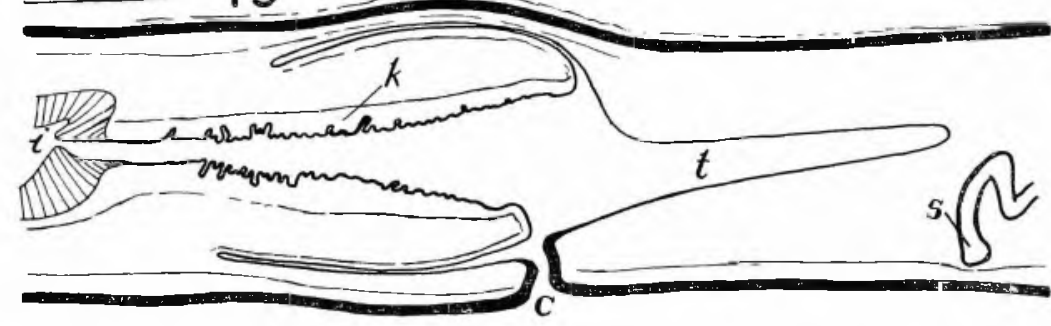

$0.5 m n i$

\section{0}

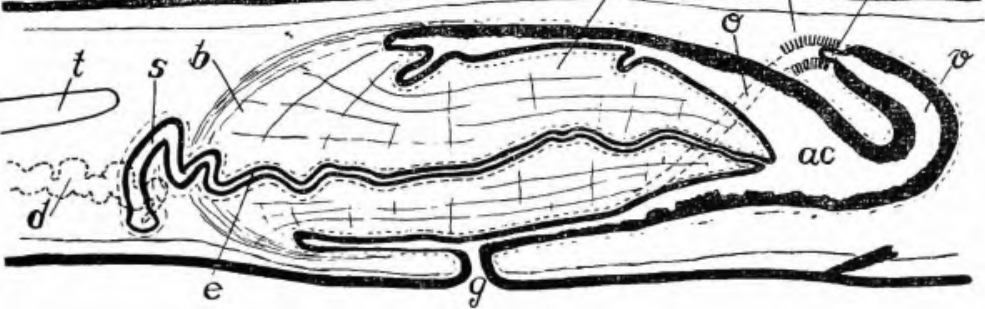




\section{PLATE 4}

Geoplana schubarii, n. sp.

(also pl. 2, Figs. 13-15; pl. 3, Figs. 16-20)

Fig. 22 - Pharynx and copulatory apparatus, combined sagittal sections (larger worm from Piraquara).

Geoplana tapira, n. sp.

(also pl. 3, Fig. 21)

Fig. 23 - Dorsal view of anterior portion of the body, showing the distribution of the eyes.

Fig. 24 - Pharynx, median section.

Fig. 25 - Copulatory apparatus, combined sagittal sections.

Geoplana toriba, n. sp.

(also pi. 5, Fig. 27-30)

Fig. 26 - Pharynx, median section.

a, male atrium; ac, common genital atrium; b, penis bulb; $c$, mouth; $\mathrm{d}$, efferent duct; e, ejaculatory duct; g, gonopore; $\mathrm{i}$, intestine; $\mathbf{k}$, muscularis of pharynx; o, oviduct; $p$, penis papilla; $q$, common glandular duct; $r$, mass of cells of female atrium; $s$, seminal vesicle; $t$, pharynx pocket; $v$, female genital canal (vagina); $z$, shell glands. 

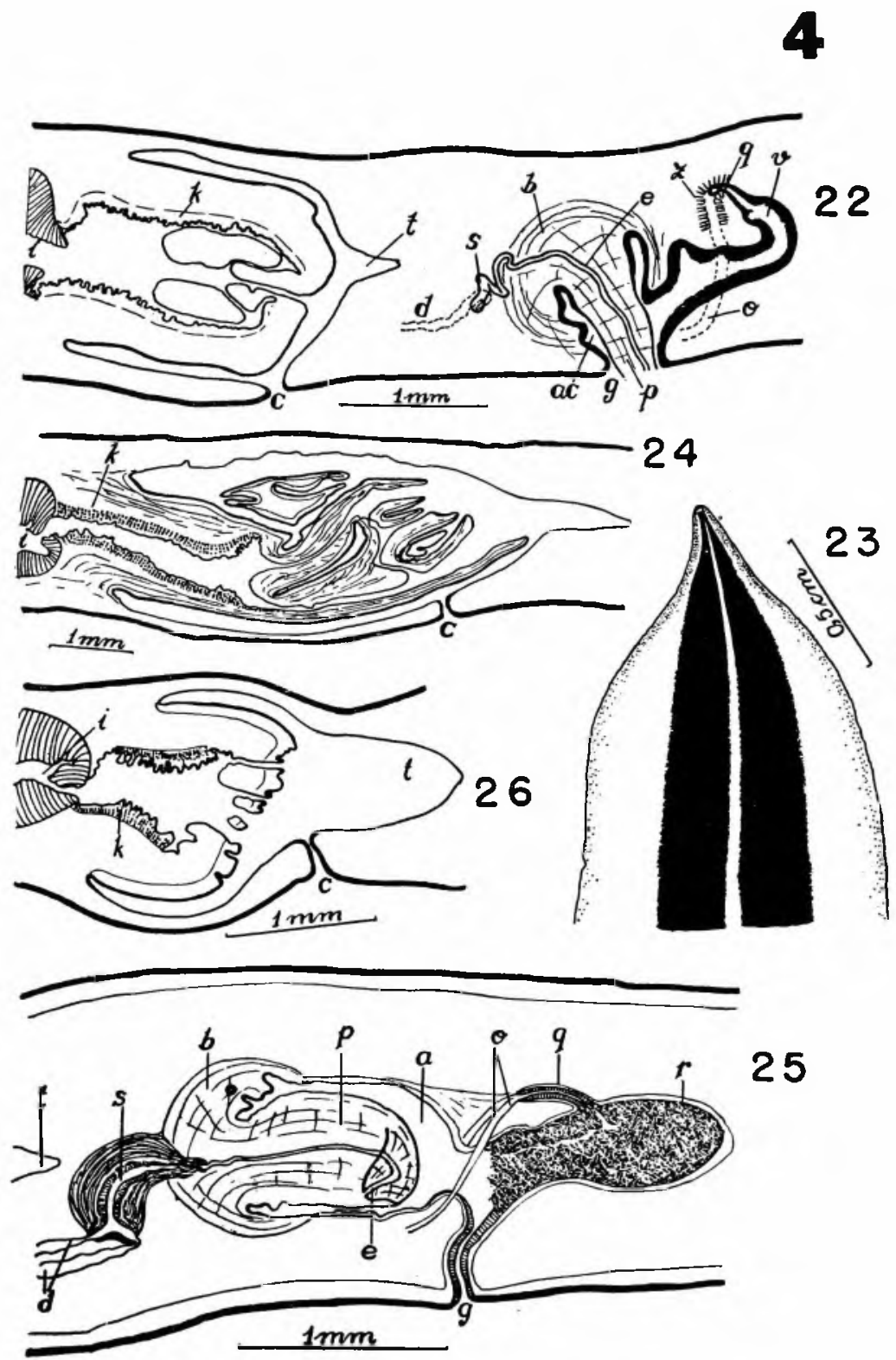


\section{PLATE 5}

Geoplana toriba, n. sp.

(also pl. 4, Fig. 26)

Fig. 27 - Copulatory apparatus, combined sagittal sections.

Fig. 28 - Dorsal view of the preserved worm.

Fig. 29 - Distribution of the eyes at the anterior end. The tip is missing.

Fig. 30 - Distribution of the eyes farther back.

$$
\begin{aligned}
& \text { Issoca potyra, n. sp. } \\
& \text { (also pl. 6, Figs. 35-38) }
\end{aligned}
$$

Fig. 31 - Dorsal view of the anterior end.

Fig. 33 - Distribution of the eyes at the anterior end.

Fig. 34 - Distribution of the eyes farther back.

a, male atrium; b, penis bulb; d, efferent duct; e, ejaculatory duct; $f$, female atrium; g, gonopore; o, oviduct; $p$, penis papilla; $q$, common glandular duct; s, seminal vesicle; y, eosinophilous glands; $z$, shell glands. 
On a Collection of Brazilian Land Planarians

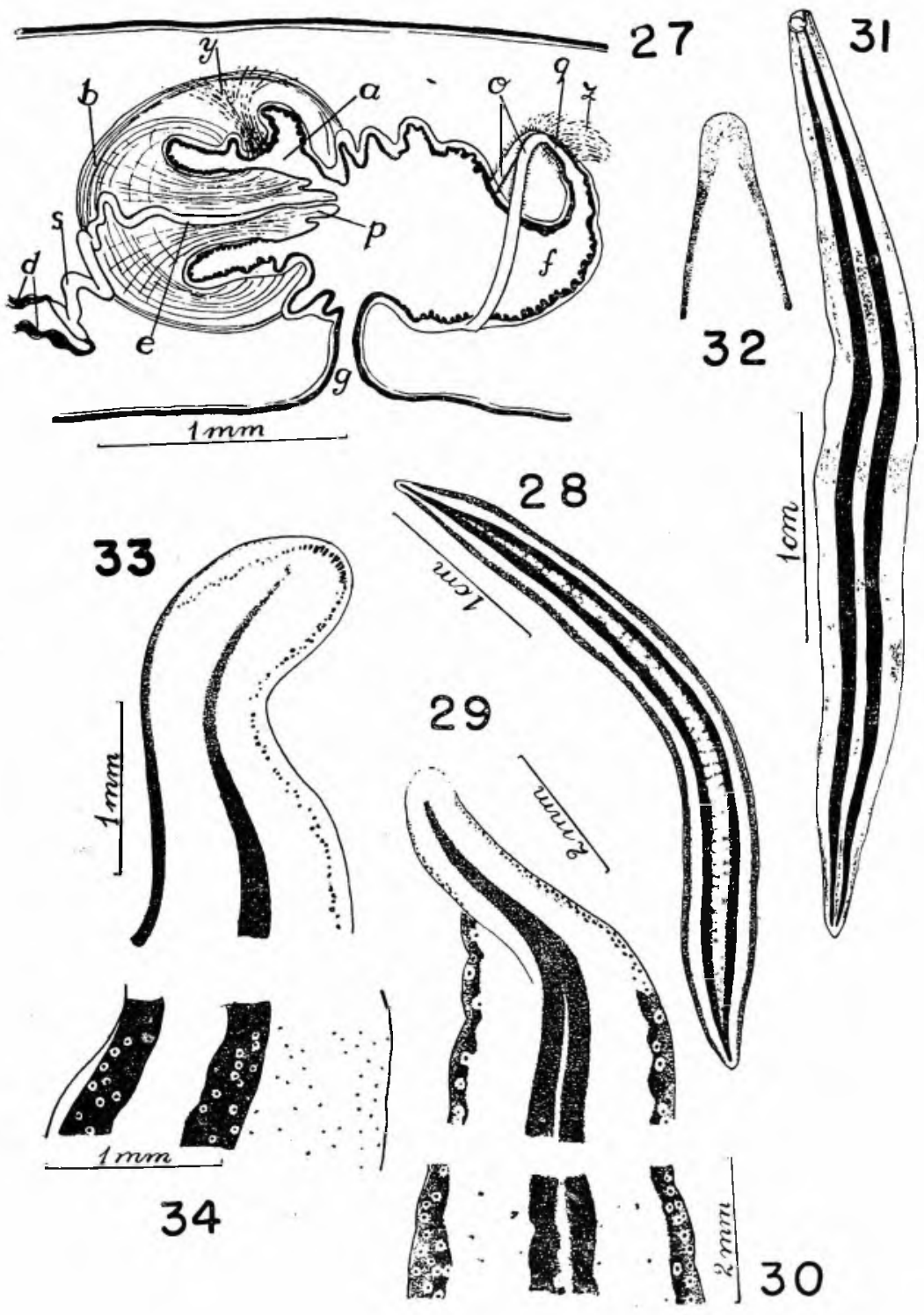




\section{PLATE 6}

Issoca potyra, n. sp.

(also pl. 5, Figs. 31-34)

Fig. 35 - Median section of the glandulo-muscular organ.

Fig. 36 - Pharynx, median section.

Fig. 37 - Copulatory apparatus, combined sagittal sections .

Fig. 38 - Detail of seminal vesicle, showing the interconnections seen from the left side.

a, male atrium; b, penis bulb; c, mouth; $d$, efferent duct; dv, dorsoventral muscles; e, ejaculatory duct; f, female atrium; g, gonopore; $\mathrm{i}$, intestine; $\mathrm{k}$, muscularis of pharynx; $1 \mathrm{c}$, subepidermal longitudinal muscles; nc, nerve plate; ne, submuscular (cutaneous) nerve plexus; o, oviduct; oc, eye; p, penis papilla; q, common glandular duct; re, retractor of glandulo-muscular organ formed by ventral subepidermal longitudinal muscles; s, seminal vesicle; sa, glandular (adhesive) surface of glandulo-muscular organ; $t$, pharynx pocket; $t r$, transverse muscles; $w$, cyanophilous glands; $x$, dorsal muscular fold separating male from female atrium; y, eosinophilous glands; $z$, shell glands. 


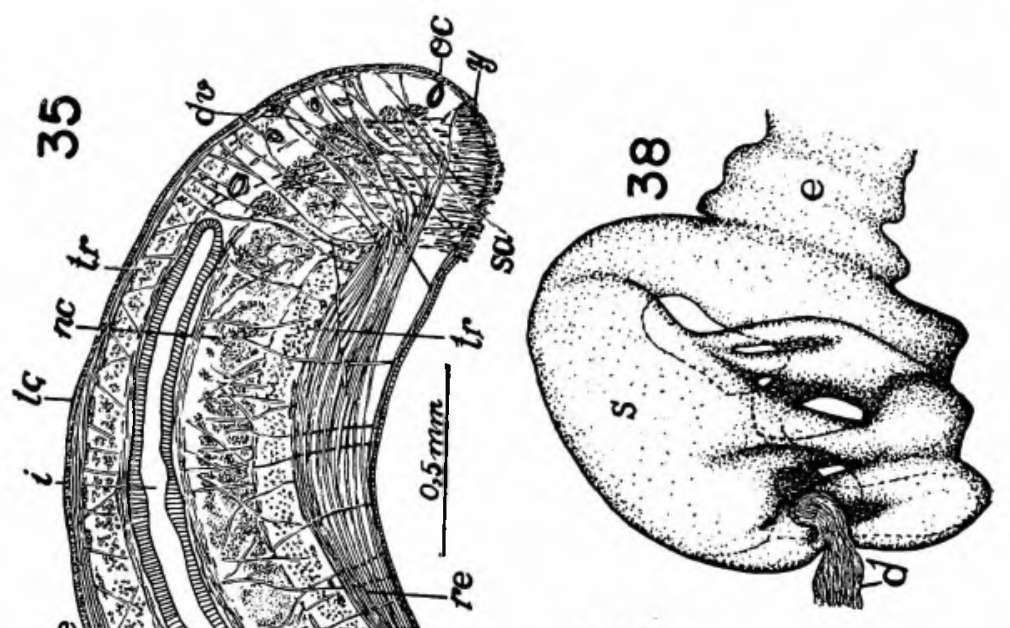

\& 1 ;

8.
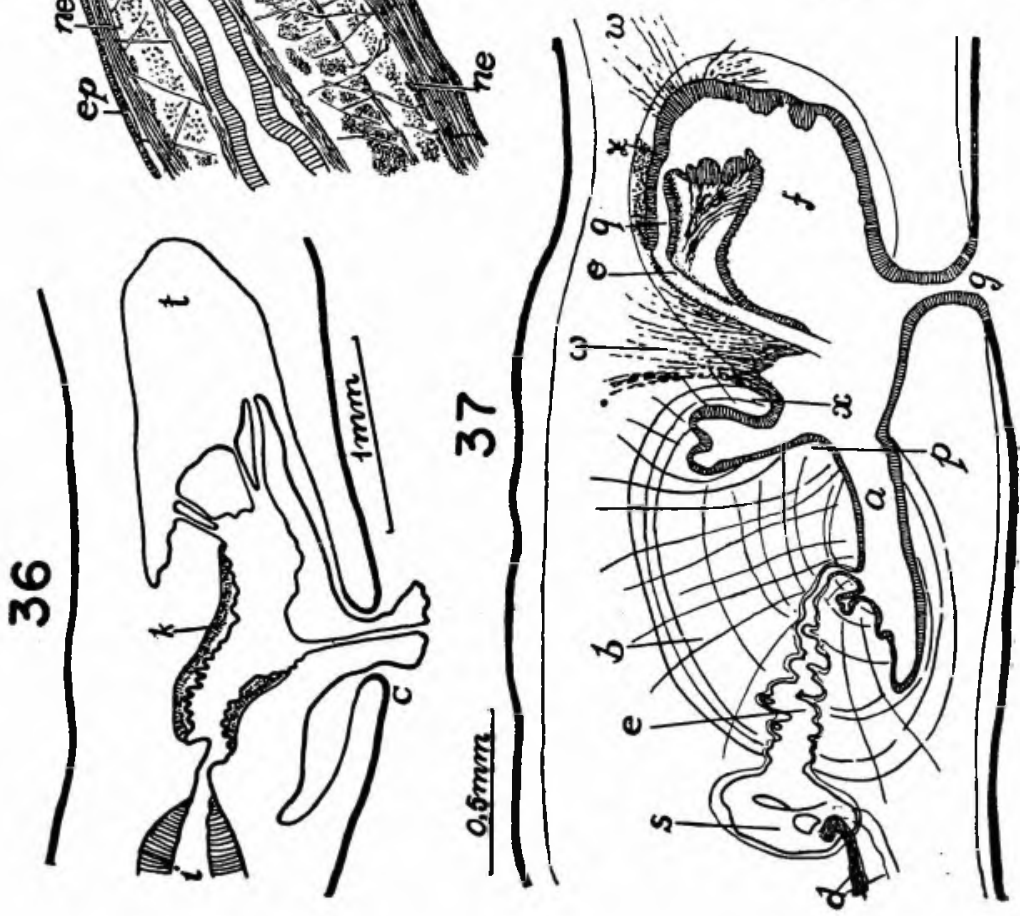
